\title{
NEWEST DETERMINANTS OF PRACTICE-ORIENTED \\ TRAINING OF TOURISM SPECIALISTS \\ IN A POLICULTURAL EDUCATION ENVIRONMENT
}

\section{НОВІТНІ ДЕТЕРМІНАНТИ ПРАКТИКО-ЗОРІЕНТОВАНОЇ ПІДГОТОВКИ ФАХІВЦІВ СФЕРИ ТУРИЗМУ ПОЛІКУЛЬТУРНОМУ ОСВІТНЬОМУ СЕРЕДОВИЩІ}

\author{
Nataliia Vasylyshyna ${ }^{1}$ \\ Tetiiana Skyrda ${ }^{2}$ \\ Ruslan Slobozhenko ${ }^{3}$
}

DOI: https://doi.org/10.30525/978-9934-588-15-0-2

Abstract. The purpose of the paper is to emphasize on the fact that international tourism is inextricably linked with the development of the world economy. Ukraine, which is part of this segment, should closely monitor and participate in the changes. At the same time, the state authorities can use the national natural and historical and cultural potentials to develop the tourism industry to the European level. To do this, it is necessary to improve the legislative framework, establish infrastructure, carry out various marketing activities. Moreover, the given article outlines key milestones which content that, at the present stage, when vocational education, in particular, tourism, mediates integration processes, the service industry needs professionals who possess innovative technologies and programs, features of communication with clients, foreign languages and tolerant thinking. Methodology. The deep scientific investigation presents modern factors that have sufficient impact as well as implications on the preparation of tourism specialists in the frame of tertiary education. Consequently, each of them was discussed and justified in separate section. They were titled in the following framework:

\footnotetext{
${ }^{1} \mathrm{Ph} . \mathrm{D}$. in Pedagogical Sciences, Associate Professor, Associate Professor at Foreign Language Department, National Aviation University, Ukraine

${ }^{2}$ Senior Teacher at Foreign Language Department,

National Aviation University, Ukraine

${ }^{3}$ Senior Teacher at Foreign Language Department, National Aviation University, Ukraine
} 
"Education in the context of European integration processes", "Studying of domestic and foreign experience of research of the problem of training specialists in the field of tourism", "The current state of vocational training of students of higher education institutions in Ukraine", "Academic mobility of tourism professionals in a multicultural environment", "Tourism education of the XXI century is on the urgency among the modern scientific community". Outcomes of the survey witnessed that contemporary factors of tourism undergraduates training in the frame of tertiary education is aimed at: providing free access to information to students; support for international academic mobility; mutual benefit of human and financial aspects of inter-university exchanges; supporting the development of international cooperation in quality assurance in education; stimulation of innovative activity of specialists providing the preparation and functioning of international educational programs engaged in international advertising of universities; the need to create their own educational space as an effective way of preparing for the equal competition of Ukrainian universities with European ones. Practical implications. Consideration and implementation of core factors of tourism students' preparation might enhance, improve and make the educational process more effective in Ukraine. In addition, outlined determinants are very likely to approach domestic education to the international community that, in its turn, are going to make future professional much more competitive in the job market. Value/originality. Close cooperation with the EU can have a positive impact on the domestic economy as a whole. In particular, the tourism industry can become one of the main directions of economic development of the state.

\section{1. Ветуп}

Сьогодні світ охоплюють процеси глобалізації, які несуть соціальні суперечності і видозмінюють якість рівня життя та освіти. Вагомого значення набуває розвиток інформаційних технологій; прагнення світовим товариством формувати нові цінності загальнолюдської культури, серед яких провідними є толерантність, повага до представників інших культур, схильність до співпраці з ними, до взаємозбагачення культур; домінуванням західного цивілізаційного простору у економічному, науково-технічному та культурному житті людства, що носить споживчий характер до духовних цінностей суспільства. Але 
в наш час існує низка проблем національного туризму, серед яких особливе місце займає питання якісної професійної підготовки фахівців галузі, яке і стало об'єктом нашого педагогічного дослідження. Одним із шляхів вирішення зазначеної проблеми є звернення до провідних ідей зарубіжного досвіду. У цьому контексті можна представити мету дослідження, яка полягає у висвітленні та практично-теоретичному обгрунтуванні новітніх детермінант підготовки фахівців сфери туризму в полікультурному освітньому середовищі, що становлять інтерес для вітчизняної туристської науки.

Методологічну основу дослідження становлять: основні положення теорії пізнання, теорії систем й теорії управління, положення гуманістичної філософії освіти, соціології, педагогіки, психології, економіки; новітні філософські, соціологічні, психолого-педагогічні ідеї щодо модернізації туристичної освіти в Україні; системний, діяльнісний, особистісний, синергетичний, компетентнісний та культурологічний підходи до вивчення системи неперервної туристської освіти, загальнонаукові принципи цілепокладання, історизму, полікультурності, наступності й прогностичності у розвитку освіти, положення щодо цілісності і наступності змісту ступеневої підготовки фахівців для сфери туризму, неперервності у розвитку професіоналізму особистості впродовж життя.

Відповідно до об'єкта, предмета, мети, концепції та гіпотези визначено такі завдання дослідження: виявити й охарактеризувати нові детермінанти підготовки майбутніх фахівців сфери туризму в Україні, а також виокремити провідні тенденції у кожному з них.

\section{2. Освіта в умовах євроінтеграційних процесів}

На сьогодні Україна намагається приєднатися до євроінтеграційних процесів, які позитивно вплинуть на становлення та розвиток окремих галузей економіки. Це, у свою чергу, надасть можливість створити нові робочі місця, поліпшити соціальну сферу, покращити товарообіг з країнами Свросоюзу. Сьогодні дослідження проблеми впливу чинників євроінтеграції на становлення, туризму України залишається актуальним у вітчизняній науці.

Цією тематикою цікавилися В. Артеменко, В. Списка, В. Гречаник, С. Зікеєва, О. Краєвська. Вони приділяли увагу різним аспектам спів- 
праці України з ЄС у туристичній галузі. Відмітимо, що сьогодні євроінтеграційні процеси дають змогу країні створити спеціальні інститути, які дозволять функціонувати в загальноєвропейському просторі. Для вітчизняної туристичної галузі це дуже важливо, так як Україна володіє значним рекреаційним та культурним потенціалами, який дає можливість розвивати різні напрямки туризму: зелений, курортний, пізнавальний, діловий, лікувально-оздоровчий [4].

На сьогодні Україні дуже важливо налагодити тісні економічні, політичні та культурні відносини з СС. Так як від цього залежить подальший розвиток держави в європейському просторі. Значну увагу державна влада приділяє саме розвитку відносин з СС у галузі туризму. Проаналізуємо напрацювання вчених О. Краєвської, Ю. Присяжнюк та С. Зікеєвої, які розглядали розвиток відносин з ЄС на початку XXI ст. в правовому та соціально-економічному полі. Виділимо основні аспекти розвитку відносин ЄС та України в туристичній сфері. При цьому автор виділить деякі нормативні документи та економічні аспекти розвитку вітчизняного туризму в загальноєвропейській площині [1].

Співробітництво, зокрема, зосереджується на таких напрямах:

- обміні інформачією, найкращими практиками, досвідом та передачі «ноу-хау», зокрема інноваційних технологій;

- встановленні стратегічного партнерства між державними, приватними та суспільними інтересами з метою забезпечення сталого розвитку туризму;

- просуванні та розвитку туристичних продуктів і ринків, інфраструктури, людських ресурсів та інституційних структур;

- розвитку та імплементації ефективних політик $i$ стратегій, зокрема відповідних правових, адміністративних та фінансових аспектів;

- навчанні спеціалістів з туризму, а також нарощенні потениіалу в галузі туризму з метою підвищення стандартів якості надання туристичних послуг;

- розвитку і сприянні туризму на основі місиевих громад [6].

На нашу думку, євроінтеграція $\epsilon$ важливим аспектом у розвитку вітчизняної туристичної галузі. Державна влада, а передусім громадянське суспільство, зацікавлені в інтенсифікації відносин України з ЄC у галузі туризму, адже вказаний процес може привести до низки 
переваг: збільшення туристичних потоків на території України, значні вливання іноземних інвестицій, поліпшення якості надання туристичних послуг, розбудова вітчизняної інфраструктури, поповнення державного та місцевих бюджетів.

На сучасному етапі, коли професійна освіта зокрема туристична, виступає посередником інтеграційних процесів, сфера послуг потребує професіоналів, які володіють інноваційними технологіями та програмами, особливостями спілкування з клієнтами, іноземними мовами та толерантним мисленням.

Проте сучасні тенденції розвитку туризму створюють нові умови для підготовки професійних та компетентних кадрів з їх подальшим працевлаштуванням. Тому, завдання удосконалення організації учбового навчального процесу в підготовці спеціалістів туристичної діяльності, формування їх професійних і ділових якостей на сьогодні $\epsilon$ ведучою, як для програми подальшого розвитку туризму так і для становлення освітньої системи в країні в нових перехідних умовах.

Однією з проблем на шляху до розвитку туристичної галузі є підготовка кадрів. У 2011 році за даними державної служби статистики України на території України здійснювало діяльність 4791 суб'єкт туристичної діяльності, а зайнята на них середньооблікова чисельність штатних працівників становила 14,4 тис. осіб. Проте лише половина з них має вищу та середню спеціальну освіту в галузі туризму - 7,5 тис. осіб. Це свідчить про певні проблеми у підготовці фахівців з туризму [5].

Тому з огляду на важливе економічне значення туризму, на його стрімкий та глобальний світовий, а також прагнення Украйни інтегрувати у світове туристичне суспільство, є доцільною модернізація складу професійної туристичної освіти.

\section{3. Вивчення вітчизняного та зарубіжного досвіду досліджень проблеми підготовки фахівців в сфері туризму}

Питання розробки методики підготовки кадрів туристичного напряму економіки досліджували ряд вчених І.В. Зорін, Е.Н. Гараніна, И.А. Зязюн, В.А. Квартальнов розглядали досвід підготовки майбутніх фахівців туристичної сфери в Україні та світі. А.Ю. Волкова займалася оглядом професійно-практичної підготовки майбутніх фахівців туристичного профілю як проблеми порівняльної педагогіки [5]. 
Н.А. Фоменко вивчала методологічні засади формування стандартів туристської освіти. П.М. Олійник розглядав інноваційні педагогічні технології підготовки фахівців для сфери туризму, зокрема дистанційне навчання [5].

Г.С. Цехмістрова вивчала методологічні засади та організацію туристської освіти, сутність та головні завдання моніторингу освіти, а також моніторинг якості туристської освіти [7].

В.К. Федорченко досліджує практику підготовки працівників туризму в західноєвропейських країнах. Зроблено помітні кроки щодо входження української освіти в європейський і світовий простір. Приведено у відповідність із міжнародними вимогами освітньо-кваліфікаційні рівні та ступеневість освіти, триває робота над державними стандартами, що наблизить вітчизняну освіту до освітніх систем найбільш розвинутих країн, зміцнюється співпраця з більш ніж п'ятдесятьма країнами світу [5].

В.К. Федорченко звертає увагу на підготовку фахівців сфери туризму у Швейцарії, яка здійснюється в широковідомих у світі навчальних закладах - Швейцарській школі готельного менеджменту (SHMS) та школі готельного менеджменту (EHL).

Вища освіта в Швейцарії асоціюється зі спеціальністю «готельний бізнес». Швейцуарія перша у світі створила модель освіти в цій області, і ї̈ школи готельного та туристичного бізнесу вважаються еталонними.

У ході здійснення реформ поряд з власним досвідом важливе значення має використання позитивних надбань інших освітніх систем. Англійська школа представлена численними освітніми закладами туризму. Так, у Великій Британії найбільш позитивно зарекомендував себе досвід підготовки професіоналів у Корнудолл-коледжі та в Борнмутському університеті. Університет Борнмут має зв'язки з університетами багатьох європейських країн, що забезпечує його студентам можливість продовжувати навчання в іншій країні або працювати за типом «сандвіч».

Університет приймає студентів, своїх партнерів, із країн-членів СС. Це також є внеском університету в розвиток міжнародної професійної компетенції в сфері туризму. Чотири з десяти дипломованих фахівців Лозанни починають свою професійну кар'єру за межами рідної країни. 
Практично половина усіх випускників школи за час своєї професійної діяльності працювала в трьох країнах, а близько $10 \%$ - у шести і більше країнах. Ось десять провідних країн, у яких працюють випускники школи в Лозанні, які не досягли тридцятьох років: Швейцарія, Франція, США, Німеччина, Бельгія, Таїланд, Великобританія, Іспанія, Греція, Канада [6].

3 появою перших готелів, відкриваються і школи, що готують персонал для роботи в них. Перша школа готельного господарства, Ecole Hoteliere de Lausanne, відкрилася у Швейцарії в 1899 році. Слідом за нею, на початку XX століття, почали з'являтися інші. Програми цих шкіл вже не обмежувалися лише предметами з управління готелем, в курс була введена спеціалізація «Подорожі та туризм» [4].

У сучасних школах готельного бізнесу, крім готельного та туристичного менеджменту, студенти вивчають маркетинг, інформаційні технології, стратегічний менеджмент, міжнародні фінансові системи і бухгалтерський облік, контроль бізнесу, проект-менеджмент і, звичайно ж, іноземні мови. Крім обов'язкової англійської мови, на якій ведеться навчання в більшості шкіл, менеджер повинен вільно володіти франиузькою або німецькою. Практично, всі програми вищої освіти охоплюють одразу три сфери - туристичний, ресторанний i готельний менеджмент.

Крім того, навчальні заклади України, які займаються підготовкою майбутніх кадрів в галузі туризму, можуть скористатися практичним досвідом Польщі, яка від недавнього використовує наступні особливості щодо покращення практичної підготовки фахівців туристичної індустрії:

- студенти можуть висловити свої побажання та окреслити перспективи проходження практики відповідно до свого індивідуального плану підготовки;

- при організації практичної підготовки допускаються відступи від основної програми практики, передбачені регламентом навчального закладу й зумовлені особливостями індивідуального плану проходження практики студентом, специфікою діяльності бази практики,

- за умови відповідної згоди навчального закладу можливе введення інноваційних форм проходження практики: стажування за кордоном, практика при частковому працевлаштуванні студента, що дає можливість безпосередньо включитись у професійну діяльність; 
- студенти мають можливість у повній мірі скористатись перевагами навчання, побудованого за принципом по черговості в умовах професійного середовища [4].

Таким чином, отримані результати підкреслюють значимість вивчення досвіду країн Свропи з метою залучення кращого досвіду підготовки майбутніх фахівців сфери туризму на території України.

\section{4. Сучасний стан професійно-практичної підготовки студентів вищих навчальних закладів в Україні}

На сьогодні в Україні підготовкою фахівців галузі туризму займаються більше 80 вищих навчальних закладів та ще більше професійних закладів нижчого рівня акредитації. Розбудова індустрії туризму потребувала кваліфікованих фахівців з усіх спеціальностей.

Тому зараз функціонує система підготовки кадрів усіх управлінських рівнів. Спеціальна фахова освіта для туристичної галузі здійснюється майже в 70 навчальних закладах різного рівня акредитації, більшість 3 яких - вузи, що надають кваліфікацію бакалавра, спеціаліста та проводять набір магістрів на відповідні спеціальності. Усі вони об'єднані в Асоціацію працівників навчальних закладів України туристичного і готельного профілю, яка ввійшла до відповідної структури ВТО.

У класичних університетах Львова, Києва, Харкова, Сімферополя, Чернівців функціонують кафедри туризму. Фахівців для туризму готують і інші навчальні заклади Києва, Черкас, Умані, Дніпропетровська, Миколаєва, Тернополя, Одеси, Запоріжжя, Білої Церкви, Івано-Франківська, Луганська, Кіровограда, Чернігова, Ніжина та інших міст [5].

Це, безумовно, сприяє розвитку туристичної галузі, але низький ступінь співробітництва між закладами професійної туристичної освіти та підприємствами не дає можливості для становлення високоякісного не тільки теоретичного, а й практичного аспекту освіти. В цілому туристична галузь потребує підготовки фахівців за 5-ма основними напрямками:

- менеджери туризму та рекреації, які забезпечують розробку туристично-рекреаційного, оздоровчо-розважального обслуговування турів та організацію обслуговування на туристичних маршрутах; 
- фінансові менеджери (економісти), які забезпечують бізнес-планування та організацію комерційної й підприємницької діяльності в туристичних установах та фірмах;

- аніматори (фахівці з організації та розробки програм спілкування та організації дозвілля, рекреаційно-оздоровчих та реабілітаційних заходів під час організації туристичної діяльності в окремих групах та установах;

- фахівці, які відповідають за розробку та реалізацію спеціальних циклів туристично-рекреаційних занять (інструктори-методисти, гіди-провідники, тренери);

- фахівці з культурно-пізнавального туризму, екскурсійної та музейної справи [5].

В Україні здійснюється підготовка фахівців всіх перелічених вище напрямів, проте незалежно від спеціалізації однією з постійних проблем для випускників ВНЗ стає недостатність здобутих практичних навичок, коли роботодавцям необхідно проводити навчання співробітників вже на робочому місці, втрачаючи не тільки час, а й кошти, що спричиняє до своєрідного парадоксу - підприємство ставить вимогу мати обов'язковий досвід роботи в туризмі при прийомі на нове місие прачі в той час, як випускник ВНЗ не може здобути ияього досвіду, оскільки не може знайти роботу з иієї ж причини [5].

Спрямованість України до вимог СС потребує розробки нових освітніх моделей професійної підготовки фахівців туризму, здатних забезпечити сталий розвиток туризму. Нинішня криза освітньої системи пов'язана з тим, що будучи за своєю природою явищем консервативним, освіта у своєму розвитку відстає від динамічного суспільного розвитку. А випускники навчальних закладів, зустрівшись з викликами вільного ринку, часто відчувають розгубленість, труднощі у вирішенні професійних і життєвих проблем [1].

На відміну від європейських країн із стійкою історичною традицією розвитку туризму, Україна змушена фактично заново, хоча й не на порожньому місці - створювати сучасну національну систему. Але без минулого не побудуєш майбутнього. Тому складається думка, що сьогодні недостатньо одних теоретичних знань. Усі ці обставини вимагають формування у майбутніх фахівців істотно нових якостей. 
Якісна професійно-практична підготовка студентів вищих навчальних закладів є складовою навчального плану та необхідною передумовою працевлаштування випускників і спрямовується на їх захист від безробіття. Висока конкуренція на ринку праці змушує вищі навчальні заклади розробляти нові механізми співпраці з галузевими підприємствами задля підвищення ефективності навчання. Знання є необхідним, але недостатнім результатом навчання на сучасному етапі розвитку суспільства, оскільки не забезпечує готовність студента до самостійної діяльності. Уміння - це здатність оперувати знаннями при вирішенні професійних завдань.

У зв'язку з цим метою освітніх закладів $є$ не стільки підготовка кадрів з грунтовними знаннями, скільки глибоко мотивованих спеціалістів з розвиненими професійними навичками, готових до виконання відповідних до фаху розумових чи фізичних дій, творчих особистостей, здатних аналізувати соціально-економічні зміни в суспільстві та розробляти перспективні програми розвитку як окремо взятого підприємства так і галузі чи держави.

Практична підготовка завжди була невід'ємною частиною навчального процесу у закладах туристичного профілю, іiі значення підсилюється специфікою таких дисциплін як «Активний туризм», «Технологія туристичної діяльності», «Технологія готельної справи», «Організація екскурсійних послуг», «Організація транспортних послуг», які мають чітко окреслений прикладний характер, і опанування яких формується на основі предметно-практичної діяльності. Практика майбутніх фахівців з туризму забезпечує розширення сфери пізнання студентів завдяки спостереженню за здійсненням операцій працівником підприємства, його активність, діяльність, у процесі якої на основі знань розвиваються фахові вміння та навички, відбувається професійне становлення майбутнього спеціаліста [4].

Вітчизняні реалії процесу підготовки фахівців галузі туризму часто показують, що теоретична підготовка кадрів в Україні в більшості проводиться належним чином та в достатньому обсязі охоплює різноманітні необхідні дисципліни та навчальні предмети, але під час проходження практики значна кількість туристичних підприємств не хоче витрачати свій час для влаштування на практику студентів, або ж використовує їхню практику в якості безкоштовної робочої сили для 
дрібних доручень (наприклад, в якості кур'єрів), що пізніше негативно позначається на практичній підготовці цих студентів.

Крім того, варто враховувати то факт, що проходження практики студентів в переважній більшості припадає на кінець весни - початок літа, коли в туристичних компаніях проходить пік сезону і туристичної активності споживачів, а тому підприємці неохоче погоджуються на присутність практиканта, якого треба навчати роботі, забираючи тим самим час в інших працівників фірми, a, отже, і майбутній прибуток компанії. Звідси можна зробити висновок, що для більш якісного процесу набуття практичних навичок майбутніми фахівцями галузі туризму, навчальним закладам можна запропонувати змінити час проходження практики на такий, який би відповідав міжсезонню в туристичних фірмах.

У зв'язку зі зміною галузі підготовки, формуванням нових галузевих стандартів і якісною навчальною базою, програму підготовки бакалаврів з туризму у ЗУЕПУ переглянуто і зменшено кількість годин виробничої практики. Навчальним планом підготовки бакалаврів 3 туризму за спеціальністю 6.020107 «Туризм» передбачено такі форми практичної підготовки як навчальна (комп'ютерна) практика в кількості 60 годин у 3 семестрі, виробнича - 90 годин у 6 семестрі та передвипускна 90 годин у 8 семестрі. Істотне скорочення обсягу практичної підготовки підсилює іiі значення у навчальному процесі та вимагає налагодження ефективного співробітництва освітян і практиків задля повноцінного включення студентів у виробничі відносини певного сегменту туристичної галузі та всебічного використання його потенціалу [4].

3 метою запобігання відтворення негативних проявів усталених методів вважаємо за доцільне вказати на типові недоліки в організації професійно-практичної підготовки фахівиів сфери туризму на сучасному етапі:

- декларативний характер договорів вищих навчальних закладів $з$ туристичними організачіями;

- закріплення студентів за певними службами туристичного підприємства та опанування ними технології діяльності окремо взятого відділу, а не вивчення досвіду роботи в цүілому;

- низький рівень набутого студентами досвіду, який грунтується на виконанні простих завдань та практичній відсутності намірів працівників галузі структурувати обсяг виконання студентами операцій; 
- низький кваліфікаційний рівень задіяного персоналу підприємства для організації якісної практики та відсутність мотивації, перспективи кар'єрного росту для керівника практики з боку навчального закладу [4].

Отже, звідси можна зробити висновок, що на сьогодні в Україні туристична освіта знаходиться на досить високому рівні, особливо зі сторони теоретичного навчання, проте існують деякі проблеми щодо практичної підготовки потенційних кадрів в галузі туризму, спричинені доволі низьким рівнем взаємодії навчальних закладів та підприємств туристичної індустрії. Тому важливим залишається питання ефективної співпраці між ВНЗ та туристичними компаніями, оскільки обидві сторони зацікавлені в якісній підготовці фахівців туризму ВНЗ прагнуть забезпечити свою престижність та якість освіти, а підприємці хочуть залучати до праці висококваліфікованих кадрів [7].

Проте варто зазначити, що система туристичної освіти в Україні знаходиться лише в стадії свого розвитку, і залишається вирішити багато важливих завдань для досягнення високого рівня професійної підготовки кадрів.

Розв'язання цих важливих завдань гальмується низкою суперечностей, зокрема між:

- вимогами ринку праці до професійної підготовки фахівців сфери туризму та рівнем їхньої кваліфікації, що не відповідає сучасним світовим тенденціям і зростаючим потребам в умовах інформаційно-технологічного розвитку;

- необхідністю підвищення рівня фундаментальності туристської освіти та недосконалістю професійно-кваліфікаційної структури кадрів;

- процесами гуманізації, гуманітаризації освітньо-виховної діяльності та їх формальним врахуванням у професійній підготовці майбутніх фахівців для сфери туризму;

- потребами культурологічної підготовки фахівців для сфери туризму з урахуванням етнонаціональних, соціально-культурних та інших особливостей різних регіонів й недооцінкою цього напряму через відомі ідеологічні причини;

- необхідністю врахування особливостей становлення і розвитку вітчизняної системи туристської освіти, прогресивних ідей зарубіжного досвіду професійної підготовки фахівців для сфери туризму та їх 
недослідженістю у вітчизняній педагогічній науці, нерідко ігноруванням у педагогічній практиці;

- зростаючим потребами щодо теоретичного обгрунтування і науково-методичного забезпечення розвитку і функціонування туристської освіти і відсутністю в Україні спеціалізованих науково-дослідних інституцій.

Існує три аспекти підготовки фахівців, що важливі для будь-якої сфери туризму. А саме:

- фундаментальне навчання (теоретичні знання), яке відповідає за отримання знань згідно навчальному плану спеціальності;

- технічне навчання (практичні знання), яке відточує майстерність і розробляє навички, необхідні для даної спеціалізації;

- особисті здібності (психологія і самовдосконалення), що відображають особисті якості фахівця [5].

Таким чином, головною метою туристичної освіти є покращення їі якості з урахуванням тенденцій розвитку світового туризму, досвіду провідних профільних навчальних закладів та потреб національних підприємств.

\section{5. Академічна мобільність фахівців сфери туризму у полікультурному середовищі}

Активна міжнародна співпраця у сфері освіти та науки нашої держави 3 іншими країнами дозволяє створити єдиний європейський освітній простір - зону «Європейської вищої освіти». У рамках нового співробітництва освіта набуває обєктивності, прозорості, конкурентноздатності, а роль українських університетів є подвійною: забезпечити належне навчання для своїх студентів та сприяти максимальному використанню можливостей студентського творчого

потенціалу в освітньому просторі передових держав, щоб забезпечити процвітання українських ВНЗ в майбутньому [1].

Реформування української освіти, запровадження положень Болонської декларації створюють передумови для ефективного здійснення крос-культурних комунікацій, розвиток якого зіштовхується з цілим рядом труднощів різного порядку та походження. Також престижним сьогодні є здобуття диплому в іншій країні та набуття нових професійних навичок і досвіду для студентів, що зумовлює такий процес як академічну мобільність. 
Академічна мобільність - це можливість упродовж періоду навчання провчитись один або більше семестрів в іншому вищому навчальному закладі, де готують фахівців з цієї ж спеціальності із зарахуванням дисциплін (кредитів) та періодів навчання; ефективніше розвивати особистий інтелектуальний потенціал. Академічна мобільність $є$ явищем динамічним, бо саме це - форма інтернаціоналізації освіти, що сприяє інтеграції індивіда до міжнародної системи освіти. Вона є: важлива складова процесу інтеграції вищих навчальних закладів у міжнародний освітній простір; період навчання студента в країні, громадянином якої він не є; виїзд певної кількості студентів для навчання за кордон; важлива якісна особливість європейського простору, що передбачає обмін людьми між вищими навчальними закладами та між державами; це можливість обрання найкращих варіантів навчання для підготовки сучасного фахівця [2].

Процес академічної мобільності також передбачає отримання додаткової (паралельної) освіти, нові професійні освітні стандарти, моніторинг якості освіти, рейтинги ВНЗ, оновлення змісту навчання (перегляд і модернізація програм, навчальних матеріалів, літератури, засобів навчання), розробку і впровадження нових навчальних дисциплін із перспективних наукових напрямів, насамперед міжгалузевих та прикладних); комп'ютеризація навчання та управління; побудову навчально-виховного процесу на засадах вільної творчої освіти (Liberal Arts Education), свободу вибору індивідуальної навчальної програми, вибіркові дисципліни, сертифікатні програми, одержання додаткової спеціальності (major \& minor), посилення творчої та самостійної складової навчання, створення інноваційно-освітніх центрів; демократизм у стосунках викладачів та студентів, посилення ролі студентського самоврядування; прозорість вступного тестування [2].

Студентська академічна мобільність - це процес здобуття студентом знань і навичок у ВНЗ країни, в якій він не має статусу громадянина. Цей процес передбачає безпосередній перетин кордону фізичною особою, з урахуванням попередньо здобутої освіти та з присвоєнням кваліфікацій чи наукового ступеня по закінченню терміну навчання. За способом організації існують два варіанти академічної мобільності: організована (здійснюється в рамках економічного, політичного або міжуніверситетського академічного партнерства) та індивідуальна 
(з власної ініціативи студента). Відповідно до мети розрізняють горизонтальну мобільність (навчання в іншому ВНЗ з метою отримання певного академічного або наукового ступеня) і вертикальну (з метою отримання наступного академічного чи наукового ступеня).

Оскільки багато завдань спрямовані на формування єдиного світового освітнього простору через співробітництво країн в галузі освіти і процесів навчання своїх громадян, то саме відкритий освітній простір сприятиме мобільності студентів.

\section{6. Туристична освіта XXI століття - на вістрі актуальності серед сучасної наукової спільноти}

Тема $є$ актуальної, що підтверджується активним проведенням кроскультурних заходів. Отже, 5 грудня 2016 року на базі Львівського інституту економіки і туризму відбулася Міжнародна польсько-українська бізнес-конференція "Туристична освіта: європейський вимір» «Україна-Польща-Свропа». Під час роботи конференції було підписано угоду про міжнародну співпрацю між Львівським інститутом економіки і туризму та Державною Вищою професійною Школою в Плоцьку.

Під час конференції відбулася дискусія з актуальних проблем щодо туристичної освіти в умовах євроінтеграційного освітнього простору 3 урахуванням сучасних соціально-економічних викликів. Акцентовано увагу на важливості організації інновачійної діяльності у вищих навчальних закладах як чинника конкурентоздатності фахівців туризму, їх готовності до ефективного виконання професійних завдань реальних туристичних підприємств.

Обгрунтовано підходи до розробки компетентнісно-діяльнісної парадигми, як передумови розвитку конкурентоздатності фахівців туризму у процесі їх професійної підготовки. Наголошено на необхідності організації системної наукової роботи на всіх етапах теоретичної і практичної підготовки майбутніх фахівців.

Варто зауважити, що проблема професійно-практичної підготовки фахівців сфери туризму, яка описується нами у рамках обгрунтування дисертаційного дослідження чітко «прозвучала» в рамках конфренції, а саме: «В роботі конференції науковцями та викладачами розглянуто основні чинники розвитку регіонального туризму, сучасні форми проектної діяльності у формуванні інновацій у туристичній галузі, запро- 
поновано інновачійні підходи до організачії практичної підготовки майбутніх фахівиів туризму».

Крім того, учасники міжнародної конференції визнали, щзо сучасна туристична освіта в Украӥні має враховувати європейський досвід професійної освіти під кутом зору євро інтеграційних освітніх процесів та ринкових перетворень.

Учасники конференції перш за все через науковий підхід апелювали до численних проблем щодо забезпечення конкурентоздатності фахівців сфери туризму. На їх думку, сучасні глобалізаційні виклики вимагають серйозних змін у підходах до навчання, структури і змісту навчального процесу, мотивації навчання студентів.

На підставі представлених доповідей та матеріалів учасниками конференції прийнято низку рекомендацій щодо теоретичних і практичних засад туристичної освіти в умовах євроінтеграції.

Нами було зазначено вище яскравий приклад туристичної освіти у Франції, який сьогодні, 27 березня 2018 року знаходить своє підтвердження проведенням наступного заходу у такому формулюванні: "Історичний факультет Київького національного університету імені Тараса Шевченка, кафедра нової та новітньої історії зарубіжних країн спільно з Начіональним Еразмус+офісом в Украӥні під егідою програми імені Жана Моне у рамках проекту "Enhanced Visibility on European Integration Teaching and Research" запрошують Вас до участі у міжнародній науково-практичній конферениії: “Європейські інтеграчійні прочеси у XXI столітті: ключові тенденції, основні виклики та нові можливості». Конференція покликана сприяти консолідації національних інтелектуальних ресурсів у сфері Свропейських студій та поширенню досліджень із європейської інтеграції серед академічної спільноти України та ширшого загалу [3].

Також, висунута нами проблема недостатньої професійно-практичної підготовки фахівців сфери туризму на сучасному етапі ще раз доводиться таким освітнім європейським заходом.

У рамках нашого дослідження конкретизуємо, що 12-15 березня 2018 р., Празький інститут підвищення кваліфікації (м. Прага) запрошує взяти участь в II Міжнародній науково-практичній конференції «Проблеми та методи підготовки висококваліфікованих фахівців: європейський досвід» з можливістю одночасного стажування $в$ 
Празькому інституті підвищення кваліфікації за програмою «Організачія навчального прочесу, наукові проекти та публікачійна діяльність в університетах Свросоюзу» [7].

Напрями підготовки передбачають обговорення таких актуальних проблем: сучасні методи та технології в освіті, академічна мобільність та інтернаціоналізація навчального процесу, внесок гуманітарної освіти та сочіальних наук в формування сучасної особистості, прикладна освіта: проблеми та пріоритети розвитку.

Актуальність іншомовної складової професійно-практичної підготовки доводиться організацією II-го Всеукраїнського круглого столу 3 міжнародною участю на тему «Роль іноземних мов у соиіокультурному становленні особистості», який відбувся 29 березня 2018 року в Національному авіаційному університеті. Також проблема іншомовної підготовки роглядається на V-ій Міжнародній науково-практичній конференції «Інтелектуальна та емоційна складові навчання іноземних мов: новітні тенденції і виклики для вищої школи» 8 червня 2018 року, оргкомітет якої я, Н.М. Василишина, очолюю особисто.

\section{7. Висновки}

На нашу думку, невід'ємними теоретик-методичними засадами нової, більш якісної професійно-практичної підготовки фахівців 3 туризму в умовах євроінтеграції повинні стати:

1. Раціональне поєднання теорії і практики в процесі фахової підготовки шляхом збільшення кількості годин на практичну підготовку за рахунок скорочення надмірної теоретичної завантаженості, тобто ущільнення сітки теоретичної частини навчального плану, навчальної робочої програми та навчально-методичного комплексу дисциплін.

2. Організація практики на базі діючих готелів, туристичних агентств та підприємств.

3. Оплачувані закордонні стажування.

4. Введення у навчальний план кількох іноземних мов англійської, а також другої іноземної мови, зокрема іспанської, французької, німецької, італійської, польської та ще однієї європейської мови на вибір.

5. Поглиблення вивчення таких навчальних курсів як «Психологія» та «Конфліктологія», «Етика бізнесу» з метою покращення особистісних якостей фахівця сфери туризму. 
6. Активне залучення до іноземних програм (наприклад Європейська асоціація професійних шкіл готельного і туристчиного профілю (AEHT), Темпус (Tempus, Trans-European Mobility Partnership Scheme for University Studies), Еразмус Мундус (Erasmus Mundus), «Вікно для зовнішньої співпраці», «Жан Моне» - Розуміння Євопейської інтеграції (Jean Monnet Programme - Understanding European Integration), «Молодь у діï» (Youth in Action Programme) створених з метою співпраці та академічної мобільності у сфері туристичної освіти та набуття закордонного досвіду.

7. Імплементація інформаційно-комп’ютерних програм та технологій у зміст професійно-практичної підготовки фахівців сфери туризму в умовах євроінтеграції

8. Застосування практико-орієнтованої, або дуальної моделі в освіті туризму.

Основними принципами щодо нової освітньої політики в системі міжнародної діяльності українських та іноземних ВНЗ повинні бути: забезпечення вільного доступу до інформації студентам; підтримка міжнародної академічної мобільності; підтримка розвитку міжнародного співробітництва у забезпеченні якості освіти; стимулювання інноваційної діяльності спеціалістів; необхідність створення власного освітнього простору як ефективного способу підготовки до рівноправної конкуренції українських ВНЗ з європейськими.

Орієнтація на Болонський процес не має призводити до надмірної перебудови вітчизняної системи освіти. Навпаки, іiі стан потрібно глибоко осмислити, порівнявши з європейськими критеріями і стандартами, та визначити можливості вдосконалення на новому етапі. При цьому систему освіти не слід відокремлювати від інших сфер суспільства. Вона має розвиватися у гармонійному взаємозв'язку з суспільством у цілому, беручи на себе роль його провідника. Побудова концепції розвитку міжнародної діяльності та участь у спільних освітніх проектах мають стратегічне значення для ВНЗ. У такому випадку новітні освітні стратегії ведуть до якісних зрушень чи вдосконалення робочого процесу або структури університету та узгоджуються 3 концепцією розвитку, проблематикою наукової діяльності та навчальними планами закладу.

Очевидною є необхідність подальших досліджень міжнародного діалогу України та країн Свропейського Союзу, широкого розповсюдження 
результатів аналізу накопиченого досвіду під час організації та проведення семінарів, тренінгів, конференцій з метою активізації міжнародної діяльності українських університетів. Це надасть змогу не лише отримати доступ до сучасних технологій і методик у навчальній сфері, підвищити свою конкурентоспроможність, але й якнайшвидше стати повноправними членами світового науково-освітнього товариства.

\section{Список літератури:}

1. Бабин I.I., Болюбаш Я.Я., Грубінко В.В., Степко М.Ф., Шинкарук В.Д. Болонський процес у фактах і документах. Київ : ТДПУ, 2006. 52 с.

2. Гуляєва Н.М. Мобільність викладачів і студентів: проблеми та орієнтири. Розбудова менеджмент-освіти в Украӥні: праці 6 щоріч. міжнар. конф. (Дніпропетровськ, 17-19 лютого 2005 р.). Київ, 2005. С. 76-81.

3. Карпенко М.М. Пріоритети розвитку вищої освіти в Україні в руслі загальноєвропейських тенденцій. Стратегічна панорама. 2004. № 3. С. 15-21. URL: http://www.niurr.gov.ua (дата звернення: 25.10.2019).

4. Кремень В.Г. Основні засади розвитку вищої освіти України в контексті Болонського процесу. Київ : ТДПУ, 2004. 147 с.

5. Фоменко Н.А. Проблеми інноваційної методики освітньої підготовки фахівців для галузі туризму. Туризм у XXI столітті: праці міжнар. наук.-практ. конф. (Київ, 10-11 жовтня 2001 р.). Київ, 2002. С. 455-462.

6. Сагинова О.В. Интернационализация высшего образования как фактор конкурентоспособности. Вісник ім. Г.В. Плеханова. 2004. № 1. С. 15-21. URL: https://cyberleninka.ru/article/n/internatsionalizatsiya-vysshego-obrazovaniyakak-faktor-konkurentosposobnosti (дата звернення: 12.10.2019).

7. Цехмістрова Г.С. Інноваційні технології в навчальному процесі підготовки кадрів для туризму. Нові технології навчання : зб. наук. пр. 2003. Вип. 35. С. 54-64. URL: http://www.library.sspu.sumy.ua.biblioteka tematychni spysky7.pdf (дата звернення 20.09. 2019).

\section{References:}

1. Babin I.I., Bolyubash Y.Y., Grubinko V.V., Stepko M.F., Shinkaruk V.D. (2006). Bolons'kij proces u faktah i dokumentah [The Bologna Process in Facts and Documents]. Kyiv: TDPU. (in Ukrainian)

2. Gulyaeva N.M. (2005). Mobil'nist' vikladachiv i studentiv: problemi ta orientiri [Teacher and student mobility: challenges and benchmarks]. Proceedings of the Rozbudova menedzhment-osviti v Ukraini (Ukraine, Dnipropetrovsk, February 17-19, 2005). Kyiv: Navch.-metod. centr «Konsorcium iz udoskonalennya menedzhment-osviti v Ukraini», pp. 76-81. (in Ukrainian)

3. Karpenko M.M. (2004). Prioriteti rozvitku vischoï osviti v Ukraïni v rusli zagal'no€vropejs'kih tendencij [Priorities for the development of higher education in Ukraine in line with European trends] Strateghichna panorama [Strategic panorama] 
(electronic journal), no. 3, pp. 15-21. Retrieved from: http://www.niurr.gov.ua.pdf (accessed 20 September 2019).

4. Kremen V.G. (2004). Osnovni zasadi rozvitku vischoï osviti Ukraini v konteksti Bolons'kogo procesu [Basic principles of development of higher education of Ukraine in the context of the Bologna process]. Kyiv: TDPU. (in Ukrainian)

5. Fomenko N.A. (2002). Problemy innovacijnoji metodyky osvitnjoji pidghotovky fakhivciv dlja ghaluzi turyzmu [Problems of innovative methodology of educational training of specialists in the field of tourism]. Proceedings of the: Turyzm u XXI stolitti (Ukraine, Kyiv, October 10-11, 2001). Kyiv: Znannja Ukrajiny, pp. 455-462. (in Ukrainian)

6. Saginova O.V. (2004). Internacionalizaciya vysshego obrazovaniya kak faktor konkurentosposobnosti [Internationalization of higher education as a factor of competitiveness] Vestnyk im. G.V. Plekhanova [The G.V. Plekhanov Bulletin]. Retrieved from: https://cyberleninka.ru/article/n/internatsionalizatsiya-vysshegoobrazovaniya-kak-faktor-konkurentosposobnosti.pdf (accessed 12 October 2019).

7. Cekhmistrova Gh.S. (2003). Innovacijni tekhnologhiji v navchaljnomu procesi pidghotovky kadriv dlja turyzmu [Innovative technologies in the educational process of training for tourism]. Novi tekhnologhiji navchannja: zb. nauk.pr. [New technologies of education: collection of scientific works] (electronic journal), vyp. 35, pp. 54-64. Retrieved from: http://www.library.sspu.sumy.ua.biblioteka tematychni_spysky7.pdf (accessed 20 September 2019). 